\title{
RISKS, SAFETY MEASURES AND LAW REGULATIONS IN THE FIELD OF UPHILL TRANSPORTATION OF CHILDREN AND ADULTS IN THE REPUBLIC OF SERBIA
}

\section{NORMAS LEGALES EN EL SECTOR DE TRANSPORTE VERTICAL DE NIÑOS Y ADULTOS EN LAS ESTACIONES DE ESQUÍ EN LA REPUBLICA DE SERBIA}

\author{
Dragana Janačković- Ćupić ${ }^{1}$, Robert Ropret ${ }^{2}$ \\ ${ }^{1}$ Public Company „Ski Resorts of Serbia“, Belgrade, Serbia \\ ${ }^{2}$ Faculty of Sport and Physical Education, University of Belgrade, Serbia
}

\begin{abstract}
Skiing is the sporting activity with an increased risk due to speed and conditions of movement but also because of usage of different modes of uphill transportation. Greater number of injuries and fatalities indicate that mechanisms of uphill transportation are potetnial risk points. Every individual and the society in general have interest to: (i) eliminate or diminish risks, (ii) establish and apply measures of protection from risks that cannot be eliminated by the application of measures and (iii) determine and indicate the precautions to be taken in order to avoid the risks which cannot be eliminated by the previous two ways. The subject of this paper are the risks in the skiers' transportation and the current legislation effective in this field in the Republic of Serbia. By analysing the normative acts, we established the lack of legal regulations which would clearly define the obligations of the owners and operators of rope tows, obligations of users, especially parents as well as the conditions of uphill transportation of children during training in ski schools. The paper offers real proposals for particular solutions.
\end{abstract}

Key words: Skiing / Uphill transporttation / Lift / Risks / Rules

\section{INTRODUCTION}

Skiing belongs to the category of activities involving an increased risk due to the movement at higher speed, under non-standard conditions, being surrounded by other skiers, using specific equipment and various means of uphill transport. The means of uphill transport represent potential risk locations.

\begin{abstract}
EXTRACTO
El esquí es una actividad deportiva con el riesgo aumentado para todos sus participantes. El aumento de riesgo acompaña la velocidad y las condiciones de movimiento, así como también el uso de distintos medios de transporte vertical. Un mayor número de lesiones y casos mortales demuestra que los medios de transporte vertical son lugares potenciales de riesgo. El interés de cada individuo y de la sociedad, así como también la obligación de una estación de esquí, es dirigir el riesgo, en sentido de que debe eliminar o disminuir el mismo, establecer y aplicar medidas para la protección de riesgos que no se pueden eliminar aplicando las medidas. Por el análisis de actas normativos se encontró la falta de las normas legales que definirían claramente las obligaciones de propietarios y empleados en teleféricos, las obligaciones de usuarios y sobre todo de los padres, así como también las condiciones de transporte de niños durante el entrenamiento en las escuelas de esquí. En el trabajo se han dado las propuestas concretas para las determinadas soluciones.
\end{abstract}

Palabras claves: ESQUÍ / TRANSPORTE / TELEFÉRICOS / RIESGOS / NORMAS /SERBIA 
1973 and 2012. By 1993, 13 deaths that occurred while using the means of uphill transport had been reported. In the 2010/11 season, the death toll was 0.149 per 100 million miles traveled, which is far less than in the case of lifts installed in buildings (0.441) or cars (1.330). In Europe, twice as many deaths were recorded in the same period (102) (NSSA, 2016). It is in the interest of each individual as well as in the public interest to: (a) eliminate or reduce risks; (b) define and implement measures to protect from the risks that cannot be eliminated by the implementation of measures; and (c) to define and specify the precautionary measures to be taken in order to avoid the risks that cannot be eliminated by the previously stated measures. The subject of this paper included the risks present in uphill transport of skiers as well as the current situation regarding the legal regulations governing this area in the Republic of Serbia.

\section{TYPES OF UPHILL TRANSPORT}

The means of uphill transport include: gondolas, chairlifts, draglifts (ski lifts: „plates," „anchors," conveyor belts) and specific traction installations (bob sled on rails, „zip line, etc.). In the Republic of Serbia, the Law on Railways represents the legal basis for the adoption of the Law on Cableway Installations Designed for Transport of Persons. According to this law, cableway installations are railways of special traffic and technical properties, including: cable cars, funiculars and draglines. The Law on Cableways for Transport of Persons stipulates that the term "cableways" refers to a subsystem of public transport of persons divided into: cable cars (gondolas and chairlifts), funiculars (cable railway with a wheeled vehicle), draglifts and specific traction installations (conveyor belts), whereas pursuant to Art. 3 of the Law on Public Ski Resorts cable cars and ski lifts are only defined as the means of uphill transport. According to the Regulation (EU) 2016/424 of the European Parliament ("Official Journal of the EU" as of March 31st 2016), there are "cableway installations" which include: "aerial ropeways", "drag lifts" and "funiculars" (wheeled vehicle pulled by a cable along the ground). According to the data of the Directorate for Railways, which is legally responsible for keeping various records on cableway installations in the territory of the Republic of Serbia, the total number of cableways in the territory of the Republic of Serbia is 70, out of which 42 cableways are under the responsibility of $\mathrm{PE}$ „Ski resorts of Serbia” and 28 cableways are under the responsibility of local self-governments and other legal entities. In Serbia, there is no official record of the number of accidents and injuries associated with cableway installations. It will be established after the by-laws have been enacted on the basis of the Law on Cableway Installations for Transport of Persons.

\section{RISKS ASSOCIATED WITH USING THE MEANS OF UPHILL TRANSPORT}

Potential risks related to using the means of uphill transport include: falling off chairlifts during a ride, embarking or disembarking; falls during entry, exit or ride by a ski lift; chairlift stopping; cable failures; stuck clothes or accessories (entrapment of scarves, parts of clothes or backpacks); injuries due to being hit by transport devices („,anchor”, „seat”, telescopic tow handles, etc.). Falling off a chairlift might be caused by the lack of a guardrail or its improper use or due to an inability of adults or children to handle it independently. Injuries on a draglift might be caused by its improper use (embarking and disembarking at the points which are not intended for this purpose), the lack of security systems at the exit stations (switch-offs), the lack of safeguard protection systems at risky parts (cables, reels) or due to inability of children to use it (inadequate body height, physical strength, etc.).

\section{LEGAL REGULATIONS}

The following are national and international normative documents relating to the uphill transport at ski resorts:

- Directive (EU) 2000/9/EC of the European Parliament on cableway installations

- Regulation (EU) 2016/424 of the EU Parliament of March 9th 2016 on cableway installations and repealing Directive 2000/9/EC

- Law on Public Ski Resorts ("RS Official Gazette," No. 46/06)

- Law on Cableway Installations for Transport of Persons (“RS Official Gazette," No. 38/2015)

- Rulebook on technical standards for personal cableways ("Official Gazette of the SFRY", no. 29/86) 
- Rulebook on technical standards for ski lifts ("Official Gazette of the SFRY", Nos. 2/85 and $11 / 85$ - amended)

- Rulebook on minimum technical requirements for the design, marking and maintenance of ski resorts ("Official Gazette of the Republic of Serbia," No. 46/2011)

- Rulebook on the contents, form and manner of keeping of the records of the authorization for conducting the expert inspection of cableway installations („RS Official Gazette,” No. 48/2016)

- Rulebook on the content, form and method of preparation of the safety analysis and safety report of cableways ("RS Official Gazette," No. 22/2016)

\section{Obligations and responsibilities of transport agent}

Articles 22 and 29-32 of the Law on Public Ski Resorts set forth the obligations of a ski resort in terms of control, maintenance, providing assistance to users and especially children, displaying the instructions on users' behavior when using the means of uphill transport. The Law on Cableway Installations for Transport of Persons (Article 39, paragraph 3) stipulates that cableway stations, inside the cable vehicles, as well as in the area of impact of the cableway installations must include warning signs regarding the behavior of persons. Under Article 40, it has been stipulated that the operator should prescribe general terms and conditions of uphill transport which contain the provisions on the persons who can be transported by cableways and the requirements according to which it shall be done, as well as the provisions on the persons' behaviour at cableway stations and during transport. Pursuant to the Law on Public Ski Resorts the ski resort is obliged to conclude an agreement on the insurance of skiers against the consequences related to the accidents occuring at the ski resort (Art. 33, para. 1, item 7) and pursuant to Art. 13 of the Law on Consumer Protection it has been set forth that „By purchasing a ski lift ticket, the consumer shall acquire the right to the compulsory insurance against the consequences of an accident ... at a ski resort ..."

\section{Obilgations and responsibilities of users}

The Law on Public Ski Resorts (Art. 56) lays down the rules regarding the users' behaviour during a ride.
It is prohibited to: act against safety and functioning; climb up the poles; unreasonably activate the security systems; grip a traction mehanism on the traction part of a track; leave the traction mehanism before an exit station; swerve along the track; remain on the track after a fall; swing on a chairlift; put the ski pole straps around the wrists; stop on the track; stay at the exit station; throw various objects; embark when the cableway is closed; behave contrary to the signs or instructions of the officials; use the cableway in case of inadequate physical ability to use it safely.

\section{Special obligations and responsibility of the transport agent regarding transport of children}

The Law on Public Ski Resorts (Art. 29 para. 2) sets forth the transport agent's obligation to „....provide assistance to the users and especially children in the event of an evident hazard or at the user's request." At the ski resorts managed by PE „Ski resorts of Serbia” the "General terms and conditions of transportation" have been implemented, according to which it has been stipulated (Article 11) as follows: „The children under the age of 12 are allowed to use all installations only when accompanied by an adult." This rule does not apply to the use of a draglift.

\section{Obligations and responsibilities of children's parents and other adult persons accompanying them}

In accordance with Art. 68 of the Family Law it has been specified that "parents have the right and the obligation to take care of a child." The aforementioned implies that parents and guardians are responsible for the child during the use of uphill transport and they are obliged to make sure that the child behaves in accordance with the rules of transport.

\section{Obligations and responsibilities of ski instructors}

With regard to the use of transport within the scope of the services provided by ski schools, the question put forth is related to the type of a contractual obligation the parents and the ski school have entered into. There is no doubt that a ski instructor is responsible for the child in the course of training. The 
Law on Public Ski Resorts (Art. 63) lays down that ,... the instructor is obliged to transfer knowledge about the skiing techniques and the rules of conduct applicable at the ski resort to the students" and ensure that „... the students comply with the rules of conduct on the track...”. According to the ski instructors' training curriculum designed by the Serbian Ski Association, the instructors should acquire knowledge in the field of using the means of uphill transport (methodical procedure, risks, prevention measures, rules of conduct, role of the persons employed at cableways). Under the agreement concluded between PE "Ski resorts of Serbia" and ski schools it has been stipulated that during embarking and transportation of skiing students aged up to 7 years, in case of six-seat and fourseat chairlifts, children shall sit on the inner side of a seat, accompanied by two adults sitting on the outer side of the seat, and in case of two-seaters or chairlifts of anchor type, it must be ensured that one child is transported while accompanied by one adult person.

\section{WEAKNESSES OF THE REGULATIONS AND THE MEASURES PROPOSED TO REGULATE THE SAFETY OF UPHILL TRANSPORT OF CHILDREN AND ADULTS}

The analysis of normative documents has shown that the laws and bylaws in the Republic of Serbia do not fully regulate the obligations of transport agents and users in terms of procedures and safety measures applicable to transport of adults and children. There is also a partial disagreement in respect of the definitions of "cableway installations" stated in the Law on Public Ski Resorts in relation to other laws. In this regard, it is necessary to accelerate the adoption of the by-laws that should be enacted on the basis of the Law on Cableway Installations for Transport of Persons in order to provide the conditions for issuing authorizations for the operation of cableways and carrying out the inspection of the cableways operation.

II Although there are no cableways without a guardrail active in Serbia, the transport agents are not obliged by the Law to ensure that chairlifts must be provided with this method of safeguarding the users from falling off. Also, the transport agents are not obliged by the Law to provide that the cableway elements are adjusted so that children can handle it independently. It is necessary that more detailed technical requirements regarding passenger safety are prescribed by the Law, such as mandatory guardrails installed on chairlifts including such technical characteristics so that children aged 12 or older can handle them on their own.

III According to the existing legislation, the responsibility to define the requirements for cableway transport has been transferred to the operator, without providing the basic requirements in regard to the transport of children and without determining the authority of an executive employee to assess fulfillment of the requirements for each person using the cableway transport. The Law does not provide for a clear definition of the age of a child or an adult. Therefore, it is required to prescribe: (a) the age at which a child cannot use the cableway installation independently; and (b) the child's age which involves "an older person" who can be entrusted with taking care of the child. It is necessary to lay down the criteria according to which it shall be determined whether a child is able to use the means of uphill transport safely and independently. In some countries these criteria imply the age of 6 years (Switzerland), body height of $125 \mathrm{~cm}$ (Italy and Austria) or school-aged children (Germany). PE "Ski resorts of Serbia" has put two criteria in place at their ski resorts according to which: children aged 12 or older may use the chairlifts independently and children aged 7 or younger must sit on the inner side of the chairlift seat, and be accompanied by an instructor, in case of a ski school student. The special obligations regarding transport of children need to be specified precisely by the laws and bylaws and in accordance with the realistic potentials for carrying out the mandatory supervision of children by executive employees at the ski resort (the age at which a child can use the cableway installation independently should be defined, executive employees should reduce the cableway speed during embarking, assist the child to take a seat, close the guard rail; during disembarking, they should slow the cableway down, check whether the guardrail has been lifted on time, whether the children have left the exit area, whether they have had 
their backpacks, whether they hold their ski poles properly, whether the rear binding has been released, in case of a snowboard ride, etc.).

IV There is no normative document that has envisaged how a ski instructor should organize the uphill transport of a number of children. The key question is: how many children can the instructor monitor simultaneously during transport? A possible solution is that the instructor can take care of a maximum of two children simultaneoulsy during a ride on a chairlift. For each additional child, there must be an adult present, who must also agree to take care of the child. Possible solutions are: the instructor should be the first to enter the chairlift and make sure the children disembark properly at the exit station. Embarking should be the responsibility of the cableway operator (the instructor should draw the employees' attention to safe embarking). If the instructor is the last one to get on, he/she shall request the employee at the exit station to be notified about the students' arrival (the employee shall keep watch at the exit, outside his/her closed facility). It would be ideal that two instructors, with two groups of children, are positioned at the entry and exit stations, respectively.

V As for drag lifts, it is necessary to define the characteristics of the drag lifts intended for children according to the criteria: towing speed, height of the tow rope and tow handle and slope of the track, as well as to define the requirements that must be met by a child in order to use the draglift, unless it is adjusted to be used by children.

\section{REFERENCES}

1. M. Muller, „Transport of children with chair lifts during ski instruction“. ISIA Congres, http:// www.isiaski.org/download/rovinj_mueller_en.pdf. 15. 12. 2016.

2. National Ski Areas Assotiation. NSSA lift safety fact sheet. https://www.nsaa.org/media/276290/ Lift_Safety_Fact_Sheet_2016_Revised.pdf, 10.2.2017.
VI It happens that the instructor entrusts other adults with taking care of the children, whereby it remains unclear how this responsibility has been transferred from the instructor to the adult. In practice, it happens that there is an adult who is sitting, by chance, next to the child. It may be assumed that the adult has no responsibility for the child other than to provide assistance in the case of an emergency. It is necessary to regulate a manner of confirming the consent obtained from an adult person entrusted with taking care of a child during transport. One of the possibilities of transferring and accepting the responsibility for the child is to ask the adult the following question, by addressing him/her directly: „Do you agree that the child can be transported with you and do you mind paying attention to the child?". If the adult's clear and definite answer is „Yes” then it may be deemed that he/she has accepted the responsibility for the child.

VII One of the ways to improve safety measures is to reinforce the appropriate behaviour at cableway installations by the security system.

VIII Instructors and persons employed at cableways should be trained in terms of legal standards, safety measures and methodical procedures regarding uphill transport of users of all ages and especially children, through the system of education and licensing. This segment of education must be associated with the legal standards proposed in this paper.

3. Ropert, R. (2014). Povrede u skijanju i snovbordu: epidemiologija i faktori rizika kao osnov za mere prevencije. [Injuries in skiing and snowboarding: epidemiology and risk factors as a basis for prevention measures]. Fizička kultura (68) 2:109121 


\section{DOCUMENTS}

1. Directive 2000/9 / EC of the EU Parliament from 20.3.2000. On cableways for the carriage of passengers, Official Gazette of the Republica of Serbia, dated 3.5.2000

2. General Conditions for Transport by Suspension Cableway and Lift as a General Act of PC Ski Resort of Serbia 06 no. 4268 of 29.12.2016

3. EU Parliament Regulation 2016/424 from 9.3.2016. On cableways and repeal of Directive 2000/9 / EC, Official Gazette of the EU, 31.3.2016
4. Law on Public Ski Resorts, Official Gazette of the Republica of Serbia, No 46/06

5. Law on Railways, Official Gazette of the Republica of Serbia, No.45 / 13

6. Law on Cableways for the Transport of Persons, Official Gazette of the Republica of Serbia, No. $38 / 2015$

7. Law on Consumer Protection, Official Gazette of the Republica of Serbia, No. 62/2014 and 6/2016.

Submitted: 10.7.2018.

Accepted: 15.10.2018.

Published Online First: 4.11.2019. 


\title{
ПРАВНА РЕГУЛАТИВА У ОБЛАСТИ ВЕРТИКАЛНОГ ТРАНСПОРТА ДЕЦЕ И ОДРАСЛИХ НА СКИЈАЛИШТИМА У РЕПУБЛИЦИ СРБИЈИ
}

\author{
Драгана Јаначковић-Ћупић ${ }^{1}$, Роберт Ропрет ${ }^{2}$ \\ ${ }^{1}$ ЈП Скијалишта Србије, Београд, Србија \\ ${ }^{2}$ Факултет спорта и физичког васпитања Универзитета у Београду, Србија
}

\begin{abstract}
Сажетак
Скијање је спортска активност са повећаним ризиком за све њене учеснике. Висок ризик прати брзина и услови кретања, као и коришћење различитих средстава вертикалног транспорта. Да су средства вертикалног транспорта потенцијална места ризика указује већи број повреда и смртних случајева. Интерес сваког појединца и друштва, као и обавеза скијалишта је да се управља ризиком, сходно чему треба да отклоне или смањи исте, утврде и примене мере за заштиту од ризика који се не могу отклонити применом мера. Анализом нормативних аката утврђен је недостатак правне регулативе којом би се јасно дефинисале обавезе власника и запослених на жичарама, обавезе корисника, а нарочито родитеља, као и услова превоза деце током обуке у ски школама. У раду су дати конкретни предлози за одређена решења.
\end{abstract}

Кључне речи: СКИЈАЮЕ / ТРАНСПОРТ / ЖИЧАРЕ / РИЗИЦИ / ПРАВИЛА /СРБИЈА

\section{УВОД}

Скијање припада категорији активности са повећаним ризиком због кретања повећаном брзином, у нестандардним условима, у окружењу других скијаша, користећи специфичну опрему и различита средства транспорта (Ропрет, 2014). Средства вертикалног транспорта су потенцијална места ризика. За повреде или инцидентне ситуације током транспорта у већини земаља не постоји систем евидентирања штете која се наноси појединцу. Према подацима Асоцијације ски центара Сједињених Америчких Држава (NSAA) у периоду 1973 - 2012. у САД је забележено преко 14 билиона превезених скијаша, односно преко 230 милиона превежених миља годишње. До 1993. године забележено је 13 смртних случајева током коришћења средстава вертикалног транспорта. У сезони 2010/11 број смртних случајева представља 0,149 на 100 милиона превежених миља, што је вишеструко мање него у лифтовима у зградама $(0,441)$ и аутомобилима $(1,330)$. У Европи, у истом периоду забе- лежен је двоструко већи број смртних случајева (102) (NSSA, 2016). Интерес сваког система који се бави скијањем и његовим одвијањем, али и сваког правног и физичког лица је да се: (а) отклоне или смањи ризици, (б) утврде и примене мере за заштиту од ризика који се не могу отклонити применом мера и (в) утврде и наведу мере опреза које треба предузети како би се избегли ризици које није могуће отклонити мерама из претходна два навода. Предмет овог рада је утврђивање ризика који постоје у транспорту скијаша, као и тренутна ситуација у погледу правних прописа којима се ова област регулише у Републици Србији.

\section{ТРАНСПОРТ НА СКИЈАЛИШТИМА У ЕВРОПСКОМ И НАЦИОНАЛНОМ ПРАВНОМ ОКВИРУ}

У средства вертикалног транспорта се убраjajy: гондоле, седежнице, вучнице (ски лифтови: „тањири“, „сидра“, покретне траке) и специфич- 
не вучне инсталације (боб на шинама, „zip line“ и сл.).

У Републици Србији, правни основ за доношење Закона о жичарама за транспорт лица је Закон о железници. Овим законом је регулисано да је жичара железница с посебним саобраћајнотехничким особинама, и може бити: висећа жичара, успињача и вучница. У Закону о жичарама за транспорт лица, под појмом „жичаре“ се подразумева подсистем јавног транспорта особа, и подељен је на: висеће жичаре (гондоле и седежнице), успињаче (жичара са возилом на точковима), вучнице, као и специфичне вучне инсталације (траке), док у Закону о јавним скијалиштима у чл. 3. као средства вертикалног транспорта су дефинисане само жичаре и ски-лифтови.

Према Уредби 2016/424 ЕУ Парламента („Сл. лист ЕУ“ од 31.3.2016) постоје „жичаре“ које обухватају: „висеће жичаре“, „вучнице“ и „успињаче“ (возило на точковима које се вуче по тлу). Према подацима Дирекције за железнице, која има законом утврђену надлежност за вођење разних евиденција о жичарама на територији Републике Србије, укупан број жичара на територији Републике Србије износи 70, од чега су 42 жичаре у надлежности ЈП „Скијалишта Србије“ а 28 жичара у надлежности локалних самоуправа и других правних лица. О броју несрећа и повреда на жичарама у Србији не постоји службена евиденција, и требало би да буде успостављена након доношења подзаконских прописа на основу Закона о жичарама за транспорт лица.

\section{РИЗИЦИ ВЕРТИКАЛНОГ ТРАНСПОРТА}

Једноставним сагледавањем проблема ризика у висинском транспорту, исти се могу представити као субјективни (проистичу од стране самих учесника у скијашким активностима) и објективни, којима припадају како ризици техничке природе, тако и они који проистичу из временских услова у којима се одвијају скијашке активности. У овом раду су анализирни могући ризици техничке природе, а који се могу поделити на:

- падове са седежнице током вожење, укр= цавања или искрцавања;

- падови током уласка, изласка и вожње ски лифтом;

- застоји седежнице; падови сајле;
- заглављивања одеће или додатне опреме (уплитања шалова, делова одеће или ранчева);

- судари са транспортним направама („сидро“, „седишта“, телескопске ручке и сл).

Падови са седежнице су могући због непостојања заштитне ограде, њеног неправилногкоришћењаилинеобученостиодраслих и деце да њоме самостално рукују. Повреде на вучници су могуће због неправилног коришћења (уласка и изласка на местима која нису за то предвиђена), недостатка сигурносних система на излазним станицама (исклопиви прекидачи), безбедносне заштите на ризичним деловима (сајле, котури) или необучености и недораслост деце да се њоме користе (недовољан телесни раст, физичка снага и сл).

\section{ПРАВНА РЕГУЛАТИВА ТРАНСПОРТА НА ЖИЧАРАМА}

Национална и међународна нормативна документа, која се односе на висински транспорт на скијалишту, а која су предмет ове анализе су:

- Директива 2000/9/E3 ЕУ Парламента о жичарама

- Уредба 2016/424 ЕУ Парламента од 9.3.2016. године о жичарама и стављању ван снаге директиве 2000/9/E3

- Закон о јавним скијалиштима („Сл. гласник PC“6р. 46/06)

- Закон о жичарама за транспорт лица („Сл. гласник РС“ бр. 38/2015)

- Правилник о техничким нормативима за особне жичаре (“Сл. лист СФРЈ”, бр.29/86)

- Правилник о техничким нормативима за ски-лифтове (“Сл. лист СФРЈ, бр. 2/85 И 11/85 - испр.)

- Правилник о минималним техничким условима за уређење, обележавање и одржавање скијалишта („Сл. гласник РС“ бр. 46/2011)

- Правилник о начину вођења, садржини и обрасцу евиденције овлашћења за обављање стручног прегледа жичара (“Сл. гласник РС”, бр. 48/2016) 
Јаначковић-Ћупић Д., Ропрет Р., Правна регулатива..., ФИЗИЧКА КУЛТУРА 2019; 73 (2): 277-282

- Правилник о садржини, начину израде и форми безбедносне анализе и безбедносног извештаја жичаре (“Сл. гласник РС” бр. 22/2016)

- Породични закон („Sl. glasnik RS“, 18/2005, $72 / 2011)$

\section{Обавезе и одговорност превозника}

Обавезе и одговорности провозника су прописане члановима 22. и 29-32. Закона о јавним скијалиштима у Републици Срији, у којима је наведено које су обавезе превозника у смислу контроле, одржавања, пружања помоћи корисницима, а посебно деци, истицање упутстава о понашању корисника приликом употребе средстава вертикалног транспорта.

Законом о жичарама за транспорт лица (чл. 39. ст. 3) прописано је да на станицама жичаpe, у њеним возилима, као и у подручју утицаја постројења жичаре, морају се налазити знакови упозорења у вези са понашањем корисника. Чланом 40. утврђено је да управљач прописује опште услове превоза који садрже одредбе о лицима која се могу превозити жичаром, под којим условима, као и одредбе о томе како се лица морају понашати на станицама жичаре и током превоза.

Закон о јавним скијалиштима обавезује скијашки центар да закључи уговор о осигурању скијаша од последица незгода на скијалишту (чл. 33, ст 1 тачка 7), а на основу чл. 13. Закона о заштити потрошача „Куповином ски карте потрошач стиче право на обавезно осигурање од последица несрећног случаја ... на скијалишту ...“ Овим документом није прописана премија осигурања.

\section{Обавезе и одговорност корисника}

Законом о јавним скијалиштима (чл. 56) прописана су правила понашања током вожње. Забрањено је: деловање против сигурности и функционисања; пењање на стубове; неоправдано активирање сигурносних система; хватање вучне направе на вучном делу стазе; напуштање вучне направе пре излазне станице; кривудање по траси; остајање на траси након пада; њихање на седежници; држање траке штапова на зглобовима руку; зауставаљање на траси; задржавање на излазној станици; бацање разних предмета; укрцавање када је жичара затворена; понашање супротно знаковима или инструкцијама службе- них лица; коришћење жичаре лицима која немају довољно физичких способности за безбедно коришћење. Вероватно је мали број корисника који је упознат са овим законом и његовим члановима, сходно томе, стратегија у борби за безбедно скијање морала би се одвијати кроз обуку скијања, као и континуиране активности превозника на упознавању и поштовању истих.

\section{Посебне обавезе и одговорност превозника у транспорту деце}

У Закону о јавним скијалиштима Републике Србије (чл. 29. ст 2.) наводи се обавеза превозника да „...пружи помоћ корисницима а нарочито деци у случају очигледне опасности или захтева корисника“. На скијалиштима којима управља ЈП „Скијалишта Србије” примењују се “Општи услови превоза” у којима је прописано: “За децу старости испод 12 година дозвољено је коришћење свих инсталација само у пратњи одрасле особе" (Члан 11.). Правило се не односи за коришћење вучнице.

\section{Обавезе и одговорност родитеља и одраслих у пратњи деце}

У складу са чл. 68. Породичног закона Републике Србије наводи се да: „родитељи имају право и дужност да се старају о детету“. Из наведеног произилази да су родитељи и старатељи одговорни за дете током коришћења вертикалног транспорта и да су обавезни да се увере да се дете понаша у складу са правилима транспорта.

\section{Обавезе и одговорност инструктора скијања}

Када је у питању коришћење транспорта у оквиру услуга школе скијања, отворено је питање какву врсту уговорне обавезе су склопили родитељи и школа скијања. Неспорно је да инструктор скијања има одговорост за дете током обуке. У Закону о јавним скијалиштима (чл. 63) наведено је да „.. инструктор ученицима мора да пренесе знања о техници скијања и правилима понашања на скијалишту“ и да се стара “... да ученици поштују обавезе понашања на стази...”. У плану и програму оспособљавања инструктора скијања Скијашког савеза Србије инструктори стичу знања из области коришћења средстава 
транспорта (методски поступак, ризици, мере превенције, правила понашања, улога запослених на жичари). Уговором ЈП “Скијалишта Србије” са школама скијања, регулисано је да, током укрцавања и превоза ученика скијања до 7 година, жичаром типа четворосед и шестосед, деца седе на унутрашњој страни седишта, у пратњи две одрасле особе које седе на спољној страни седишта, а на жичарама типа двосед и сидро да се превоз једног детета обавља у пратњи једне одрасле особе.

\section{НЕДОСТАЦИ У ПРОПИСИМА И ПРЕДЛОЗИ МЕРА ЗА РЕГУЛИСАЊЕ БЕЗБЕДНОСТИ ВЕРТИКАЛНОГ ТРАНСПОРТА НА СКИЈАЛИШТИМА}

Анализом нормативних докумената може се закључити да у Републици Србији законским и подзаконским прописима нису у потпуности регулисане обавезе превозника и корисника у смислу поступака и мера безбедности при транспорту одраслих и деце. Постоји делимично неслагање у погледу дефиниција “жичаре” у Закону о јавним скијалиштима у односу на остале законе. У том смислу је нопходно убрзати доношење подзаконских прописа који треба да буду донети на основу Закона о жичарама за транспорт лица како би се стекли услови за издавање одобрења за рад жичаре и вршење инспекцијског надзора над радом жичара.

II Иако у Србији не постоје активне жичаре без заштитног рама, Закон не обавезује превознике да седежнице морају да имају овај начин обезбеђења корисника од могућности пада. Такође Закон не обавезује превознике да делови жичаре морају бити прилагођени тако да деца могу самостално њиме да рукују. Законом је неопходно прописати ближе техничке детаље у вези са безбедности путника, као што су обавезна заштитна ограда на седежницама са таквим техничким карактеристикама да њима, деца од 12 и више година, могу самостално да рукују.

III Постојећа законска регулатива преноси на управљача утврђивање услова за превоз жичаром без давања основних услова у погледу транспорта деце и без утврђивања овлашћења извршног радника да врши процену испуњености услова за свако лице које користи превоз жичаром. Закон не нуди јасну дефиницију узраста детета и одрасле особе. Неопходно је прописати: (а) до ког узраста дете не може самостално да користи жичару и (6) који узраст подразумева “старију особу" којој може да се повери дете. Потребно је прописати критеријуме по којима се утврђује оспособљеност детета да самостално и безбедно користи средства вертикалног транспорта. У појединим земљама то је узраст од 6 година (Швајцарска), телесна висина од 125 цм (Италија и Аустрија) или школски узраст (Немачка). Јавно предузеће „Скијалишта Србије“ за своје ски центре прописује два критеријума: 12 година за самостално коришћење седежница и 7 година као критеријум када дете мора да седи са унутрашње стране седежнице, у пратњи инструктора, ако је у школи скијања. Законским и подзаконским прописима потребно је прецизирати посебне обавезе у транспорту деце у складу са реалним могућностима да се реализује обавезан надзор над децом од стране извршних радника на скијалишту (дефинисати узраст детета које може самостално да користи жичару, да при укрцавању смање брзину жичаре, помогну детету да седне, затворе заштитини рам; при изласку успоре, прате да ли је заштитини рам подигнут на време, да ли су деца напустила место за излазак, да ли имају ранчеве, да ли исправно држе штапове, да ли је откачило задњи вез ако вози сноуборд и др).

IV Ни један нормативни документ не предвиђа на који начин инструктор решава проблем транспорта више деце. Кључно питање је: колико деце, истовремено, може да надгледа инструктор током транспорта? Могуће решење је да инструктор током вожње на седежници може да води бригу највише над два детета истовремено. За свако ново дете мора да буде присутна одрасла особа која мора да потврди пристанак да ће водити рачуна о детету. Могућа решења су: на седежници инструктор иде први и стара се о правилном изласку на излазној станици. 
Полазак је у надлежности управљача жичаре (безбедно укрцавање о чему инструктор скреће пажњу запосленима). У случају да инструктор иде последњи, дужан је да захтева да запослени на излазној станици буде обавештен о доласку ученика (запослени дежура на излазу, ван свог затвореног објекта). Иделно је да се два инструктора, са две групе, распореде на полазној и излазној станици.

V За вучнице је потребно дефинисати карактеристике вучница намењене деци према критеријумима: брзине вучења, висина вучног канапа и ручке и нагиба стазе, као и критеријуме које мора да испуњава дете да би користило вучницу, уколико она није прилагођена за децу.

VI Дешава се да инструктор поверава децу другим одраслим особама, при чему није јасно како се та одговорност пребацује са инструктора на одраслу особу. У пракси се дешава да, стицајем околности, поред детета седи одрасла особа. Претпоставка је да одрасла особа нема одговорност према детету, осим да пружи помоћ у случају опасности. Регулисати начин потврђивања сагласности старије особе којој се поверава дете током транспорта. Једна од могућности преношења и прихватања одговорности је да се одраслој особи, у директном обраћању, постави питање „Да ли се слажете да се дете превози са вама и да обратите пажњу на дете“. Уколико одрасла особа изнесе јасан одговор „Да“ у том случају прихвата одговорност за дете.

VII Један од начина подизања мера безбедности је и да се системом осигурања и информацијама које се дају корисницима потенцира правилно понашање на жичарама.

VIII Системом образовања и оспособљавања, као и њиховог даљег лиценцирања, неопходно је истрајавати на обучености инструктора и запослених на жичарама у смислу законских норми, мера безбедности и методичких поступака при транспорту корисника свих узраста, а посебно деце. Овај сегмент образовања се мора повезати са законским нормама које су предложене у овом раду.

\section{ЛИТЕРАТУРА}

1. Muller, M. Transport of children with chair lifts during ski instruction. ISIA Congres. Dostupno15.12.2016. na http://www.isiaski.org/ download/rovinj_mueller_en.pdf

2. National Ski Areas Assotiation (1.10.2016). NSSA lift safety fact sheet. Dostupno 10.2.2017. na https://www.nsaa.org/media/276290/Lift_ Safety_Fact_Sheet_2016_Revised.pdf

3. Ропрет, Р. (2014) Повреде у скијању и сноуборду: епидемиологија и фактори ризика као основ за мере превенције. Физичка култура (68) 2:109-121

\section{ДОКУМЕНТА}

1. Директива 2000/9/E3 ЕУ Парламента о жичарама од 20.3.2000. о жичарама за превоз путника („Сл. лист ЕУ“ од 3.5.2000.)

2. Закон о железници („Сл. гласник РС”, бр.45/13)
3. Закон о жичарама за транспорт лица („Сл. гласник РС“ бр. 38/2015)

4. Закон о јавним скијалиштима („Сл. гласник PC“ бр. 46/06)

5. Закона о заштити потрошача („Сл. гласник PC», бр. 62/2014 и 6/2016)

6. Општи услови за превоз висећом жичаром и вучницом као општи акт ЈП Скијалишта Србије 06 бр. 4268 од 29.12.2016

7. Породични закон („(„Сл. гласник РС“, 18/2005, 72/2011)

8. Правилник о минималним техничким условима за уређење, обележавање и одржавање скијалишта („Сл. гласник РС“ бр. 46/2011)

9. Правилник о начину вођења, садржини и обрасцу евиденције овлашћења за обављање стручног прегледа жичара (“Сл. гласник РС”, бр. 48/2016) 
10. Правилник о садржини, начину израде и форми безбедносне анализе и безбедносног извештаја жичаре (“Сл. гласник РС” бр. 22/2016)

11. Правилник о техничким нормативима за особне жичаре (“Сл. лист СФРग”, бр.29/86)
12. Правилник о техничким нормативима за скилифтове (“Сл. лист СФРग, бр. 2/85 И 11/85 испр.)

13. Уредба 2016/424 ЕУ Парламента од 9.3.2016. године о жичарама и стављању ван снаге директиве 2000/9/E3

Примљен: 10.7.2018. Прихваћен: 15.10. 2018. Online објављен: 4.11.2019. 